\title{
FORMING OF DIASTEREOISOMER WITH L-ISOLEUCIN TO SEPARATE OFLOXACIN ENANTIOMER USING PREPARATIVE LIQUID CHROMATOGRAPHY
}

\author{
Diana Hendrati*, Husein H. Bahti, Uji Pratomo \& Zenith Putri Dewianti \\ Department of Chemistry, Faculty of Mathematics and Sciences, Universitas Padjadjaran \\ J1. Raya Jatinangor km 21, Sumedang, West Java, 45363 Indonesia \\ *Correspodency: dianahendrati2013@gmail.com
}

\begin{abstract}
Ofloxacin is an antibiotic with a broad range of uses in human and veterinary medicine to prevent or treat bacterial infections which has an enantiomeric mixture structure of (-)-ofloxacin and (+)-ofloxacin. Enantiomers of drugs have different pharmacology and toxicology effects that need to be separated before it used to get the molecule target. Separation of enantiomers using chiral column is not quite economical separation, but the separation of enantiomers using a chiral column by converting the enantiomeric mixture into a diastereoisomeric form is the right solution. This study aims to separate mixture of ofloxacin enantiomers by forming diastereoisomeric with L-isoleusine and copper (II) into compound (-)-ofloxacin and (+)-ofloxacin and also to identify the optimum condition of separation using HPLC with preparative liquid chromatography column. Samples injected into the column and eluted by the mobile phase (consisting a mixture of watermethanol (88:12) and solution of L-isoleusine $4 \mathrm{mM}$ and copper (II) sulfate $9 \mathrm{mM}$ ). Then the fractions were compared with the standard and the purity was tested by HPLC. This research resulted 47 fractions which four of early fractions have correspond with the standard of (-)-ofloxacin and 43 other factions do not. We obtained the resolution of this separtion about 0.98. The small resolution caused by complex formation is not perfect with the concentration of L-isoleucine and copper (II).
\end{abstract}

Keywords: enantiomers, diastereoisomers, ofloxacin, HPLC

\begin{abstract}
Abstrak: Ofloxacin adalah antibiotic yang digunakan secara luas sebagai obat manusia dan hewan untuk mencegah dan mengobati infeksi bakteri dan memiliki campuran struktur enansiomer (-)-ofloxacin dan (+)ofloxacin. Enansiomer obat memiliki efek farmakologi dan toksikologi sehingga perlu dipisahkan sebelum digunakan pada molekul target. Pemisahan enansiomer menggunakan kolom kiral bukan pemisahan yang ekonomis, namun pemisahan enantiomer menggunakan kolom kiral dengan mengubah campuran enansiomer dengan membentuk diastereoisomer merupakan solusi yang terbaik. Penelitian ini dilakukan untuk memisahkan campuran enansiomer ofloxacin dengan membentuk diastereoisomer dengan L-isoleusin dan tembaga(II) membentuk senyawa (-)-ofloxacin dan (+)-ofloxacin dan juga menentukan kondisi optimum pemisahan dengan HPLC metode kolom kromatografi cair preparatif. Sampel diinjeksikan ke dalam kolom dan dielusi dengan fasa gerak (terdiri atas campuran air-metanol [88:12] dan larutan $4 \mathrm{mM} \mathrm{L-isoleusin} \mathrm{dan} 9 \mathrm{mM}$ tembaga(II) sulfat). Kemudian fraksi hasil kolom dibandingkan terhadap standard an kemurniannya ditentukan dengan HPLC. Dari penelitian ini dihasilkan 47 fraksi dan empat fraksi awal sesuai dengan standar (-)-ofloxacin sedangkan 43 lainnya tidak menunjukkan hasil positif. Resolusi pemisahan yang diperoleh sebesar 0,98 . Resolusi pemisahan yang rendah terjadi karena pembentukan kompleks tidak sempurna dengan konsentrasi L-isoleusin dan tembaga(II) yang digunakan.
\end{abstract}

Kata kunci: enansiomer, diastereoisomer, ofloxacin, HPLC

\section{INTRODUCTION}

Most biological compounds for pharmacological are chiral compounds. More than $60 \%$ of the drugs used to contain asymmetric centers (chiral) but only about $25 \%$ of it are pure enantiomer (Schmid \& Gübitz, 2011).

Enantiomers are two types of chemical species with identical molecule but different from each other as mirror images that do not coincide (Wang et al., 2012). Enantiomer of drugs have toxicological and pharmacological effects that are different so that in most cases the pharmacological effects restricted to only one enantiomer (eutomer) while the unwanted enantiomer (distomer) have side effects or even toxic (Schmid \& Gübitz, 2011).. Therefore, the preparative separation of enantiomers is indispensable.

Ofloxacin is an antibiotic with a broad range of used worldwide in veterinary and human medicine to prevent or treat bacterial infections (Aydogan et al., 2013). These compounds include compounds having a chiral compound mixture of enantiomers (-)ofloxacin and (+)-ofloxacin (Fessenden \& Fessenden, 1992). (-)-Ofloxacin isomer has anti-bacterial activity 8-128 times more active than the isomer (+)ofloxacin, so before it is used as a medicine, (-)- 
ofloxacin isomer must be separated in order to be on drugs unfit for consumption (Aydogan et al., 2013).

Separation method used is preparative liquid chromatography while the purity test conducted using High Performance Liquid Chromatography (HPLC). Analysis by HPLC method has proven very useful in comparison with other analytical methods, are also cheap and easy to do. While the preparative separation is made to obtain physical forms of separation so that they can be used more pharmacologically.

Separation by chiral mobile phase is based on the formation of a ternary complex, aided by achiral stationary phase to form a chemical equilibrium. The difference in the energy of the complex stability or diastereoisomers affects the chemical equilibrium which lead to different chromatographic properties. As a result, the separation can be separated using a C18 column (Anderson et al., 2015).

Enantiomer of ofloxacin were separated by column octadecyl silica (ODS) / C18 conventional exchange ligand using a mobile phase of methanolwater (containing different concentrations of Lisoleucine and copper (II) sulfate as ligand agent and ionic ligands) successfully analyzed (Tian et al., 2010). Separation of the enantiomers of ofloxacin had previously been conducted using HPLC in optimum condition by using amino acids Lisoleucine, L-valine, L-lysine, L-phenylalanine also using copper (II) as the central atom at a temperature of $40^{\circ} \mathrm{C}$ with a mobile phase of water and methanol (88:12) to produce the best separation resolution, amounting to 2.57 for the amino acid L-isoleucine (Shao et al., 2008). It also has to do with the HPLC separation of enantiomers of ofloxacin obtained optimum conditions, i.e. the mobile phase composition of water and methanol 88:12 containing $9 \mathrm{mM}$ L-isoleucine and $4 \mathrm{mM} \mathrm{Cu}^{2+}$ with a flow rate of $0.8 \mathrm{~mL} / \mathrm{min}$ (Anderson et al., 2015). Results separation with ethanol, methanol and 1-propanol is best is by using methanol (Tian et al., 2010).

Based on these findings, it is necessary to conduct further research to produce separation and gain physical shape (-)-ofloxacin isomer through the formation of diastereoisomers with the amino acid Lisoleucine using preparative liquid chromatography so it can be expected that from the results of this study, the pure isomer (-)-ofloxacin can be used directly in the pharmacological field.

\section{MATERIALS AND METHODS \\ Materials}

Samples to be used in this study is a compound mixture of ( \pm )-ofloksasin and standard used were (-)ofloxacin compounds obtained from PT. Meprofarm. The chemicals used are double distilled water, the amino acid L-isoleucine, methanol, octadecyl silica (ODS), and copper (II) sulphate. The tools used in this study is a set of tools preparative liquid chromatography, High Performance Liquid
Chromatography Hawlet Packard 1100 series with C18 Zorbax ODS column $(4.6 \mathrm{~mm} \times 15 \mathrm{~cm})$ and UVVis detector, analytical balance, as well as tools glassware commonly used in the laboratory.

\section{Methods \\ Prepartion of Solution}

Samples ofloxacin carefully weighed as much as $100 \mathrm{mg}$ and then diluted with methanol up to $100 \mathrm{~mL}$ in a volumetric flask, thus obtained sample concentration of $1.00 \mathrm{mM}$.

Standard (-)-ofloxacin carefully weighed as much as $100 \mathrm{mg}$ and then diluted with methanol up to $100 \mathrm{~mL}$ in a volumetric flask, in order to obtain a concentration of $1.00 \mathrm{mM}$.

The amino acid L-isoleucine carefully weighed as much as $3.2792 \mathrm{~g}$, added dilute acid or basic drop by drop until dissolved, then dissolved with double distilled water up to $250 \mathrm{~mL}$ in a volumetric flask, in order to obtain a concentration of $1.00 \mathrm{mM}$.

Copper (II) sulphate weighed as much as $12.4850 \mathrm{~g}$ and then diluted to $500 \mathrm{~mL}$ of water in a flask, in order to obtain a concentration of $1.00 \mathrm{mM}$.

\section{Chromatography System}

A little cotton put in a clean and dry preparative columns then it was filled by ODS as stationary phase that have been developed previously with methanol. The stationary phase was maintained so that no hollow space built up in the column. Mobile phase of water and methanol (88:12) containing 9.0 $\mathrm{mM}$ L-isoleucine and copper (II) sulphate $4.0 \mathrm{mM}$ flowed into a continuous column (stationary phase should not be allowed to dry).

Mobile phase of water and methanol (88:12) containing $9.0 \mathrm{mM}$ L-isoleucine and copper (II) sulphate $4.0 \mathrm{mM}$ flowed into the column at a flow rate of $0.8 \mathrm{~mL} / \mathrm{min}$ and the fraction was detected at a wavelength of $293 \mathrm{~nm}$. Having obtained a baseline, the sample $( \pm)$-ofloxacin injected through the injector as much as $20 \mathrm{~mL}$ syringe. The chromatograms were interpreted and compared to a standard.

\section{Calculation of Resolution Separation (R)}

$$
R s=\frac{2\left(t_{R}-t_{S}\right)}{\left(w_{R}+w_{S}\right)}
$$

\section{RESULT AND DISCUSSION}

The separation resulted in 47 fractions, the amount of each fraction is $1 \mathrm{~mL}$. The color of each fraction were varied. Detailed data is presented in Table 1.

Cis- stereoisomer has retention times faster than trans- stereoisomers. Because in the cis- there are intramolecular interactions between amino acid with (-)-ofloxacin, so this is stereoisomer weakly hold by the columns. While the trans- position of the amino acid and (+)-ofloxacin far apart, so there is no intramolecular interactions. Intermolecular interaction occurred for trans- stereoisomer on the 
Table 1. Separation Results

\begin{tabular}{lllll}
\hline $\begin{array}{l}\text { Fraction } \\
\text { number }\end{array}$ & Fraction color & Peak & Retention Time (t) & Information \\
\hline 1 & Blue & + & 1.931 & Same as standard \\
2 & Blue & + & 1.539 & Same as standard \\
3 & Blue-green & + & 1.515 & Same as standard \\
4 & White-blue & + & 1.660 & Same as standard \\
5 & White-yellow & - & & No peak observed \\
$6-17$ & White-yellow & - & & No peak observed \\
$18-42$ & Blue-green & - & & No peak observed \\
$43-47$ & Blue & - & & No peak observed \\
\hline
\end{tabular}

column, so the retention time is longer. The results is presented on Table 2 .

Table 2. Results of samples chromatograms

\begin{tabular}{lcccccc}
\hline No & $\begin{array}{c}\text { Retention } \\
\text { time } \\
\text { (minutes) }\end{array}$ & \multicolumn{2}{c}{$\begin{array}{c}\text { Wide of Peak } \\
\text { (minute) }\end{array}$} & $\alpha$ & $\mathrm{R}$ \\
\cline { 2 - 5 } & $\mathrm{t}_{\mathrm{r}}(\mathrm{s})$ & $\mathrm{t}_{\mathrm{r}}(\mathrm{R})$ & $\mathrm{W}_{\mathrm{S}}$ & $\mathrm{W}_{\mathrm{R}}$ & & \\
\hline 1. & 1,896 & 2,062 & 0,086 & 0,354 & 1,087 & 0,752 \\
2. & 1,623 & 2,093 & 0,130 & 0,349 & 1,289 & 0,978 \\
\hline
\end{tabular}

Table 3. Results of chromatograms (-)-ofloxacin standards

\begin{tabular}{ccc}
\hline No & $\begin{array}{c}\text { Retention time } \\
\text { (minutes) } \\
\mathrm{t}_{\mathrm{r}(\mathrm{S})}\end{array}$ & $\begin{array}{c}\text { Wide of Peak } \\
\text { (minute) } \\
\mathrm{W}_{\mathrm{S}}\end{array}$ \\
\hline 1 & 1,014 & 0,2194 \\
2 & 2,038 & 0,3128 \\
3 & 2,072 & 0,3432 \\
\hline
\end{tabular}

The result of samples chromatogram fraction compared to standards. Based on the chromatogram, the retention time (-)-ofloxacin faster than the (+)ofloxacin. However, the separation produces overlaped peaks. It can be caused by the absence of $\mathrm{pH}$ control. The $\mathrm{pH}$ control associated with the separation of enantiomers which involves the formation of complex compounds. The $\mathrm{pH}$ value will determine the stability of the complex compounds. Too high or too low $\mathrm{pH}$ will cause complex compounds will not be formed. If the $\mathrm{pH}$ is too high, it will cause the formation of hydroxide deposits $\left(\mathrm{Cu}(\mathrm{OH})_{2}\right)$ which can interfere with the separation.

Based on suitability of peak retention presented on Table 1, fractions 1, 2, 3, and 4 were in agreement with standard and predicted as (-)-ofloxacin isomer. However, in addition to the four factions, the rest of the peak gave negative results. It can be concluded that the enantiomer separation did not succeed. In addition, the absence of (+)-ofloxacin standards was one factor limitations in order to compare fractions with a (+)-ofloxacin standard.

The unsuccessful separation is suspected due to incomplete formation of complex compounds between the copper (II) with L-isoleucine and (-)ofloxacin or (+)-ofloxacin. Once reviewed, the factor causing incomplete formation of complex compounds was caused by the amount of copper (II) which were not excessive. The condition was used in this study by using preparative columns, one of which the concentration of copper (II) used which is $4 \mathrm{mM}$.

In the previous study, the conditions used lead to fairly good HPLC separation with a resolution of 1.31. However, when applied for the preparative liquid chromatography, it turns out that the separation does not occur due to the concentration of copper (II) was not suitable. In the previous study, $20 \mathrm{~mL}$ with $1.00 \mathrm{mM}$ concentration of sample was injected into the HPLC column. While in this study, the samples used were $30 \mathrm{mg}$ in $0.5 \mathrm{~mL}$ of methanol (highly concentrated) and the samples did not resulted a color change in the column. So the use of copper (II) with the same concentration obviously would produce a much different result. As a solution, it is necessary to conduct further research in order to obtain significant results, namely the formation of complex compounds in the form of testing between the sample with Lisoleucine and copper (II).

\section{CONCLUSION}

From the research that has been done, we conclude the following points:

1. Separation of enantiomer of ofloxacin using preparative liquid chromatography method can not be separated completely through the formation of diastereoisomers, where only four out of 47 factions that have compatibility with the standard (-) - ofloxacin.

2. The optimum conditions of previous research for the separation of enantiomers of ofloxacin were mobile phase composition of water and methanol $88: 12$, flow rate of $0.8 \mathrm{~mL} / \mathrm{min}$, the concentration of copper (II) sulphate $4.0 \mathrm{mM}$, and a concentration of $9.0 \mathrm{mM}$ L-isoleucine with HPLC method produces separation with a resolution of 0.98 . The small size of this resolution due to the formation of complex compounds that are not perfect between the sample with L-isoleucine and copper (II).

\section{REFERENCE}

Anderson, J., Berthod, A., Pino, V., \& Stalcup, A.M. 2015. Analytical Separation Science. Wiley-Vch, Germany. 
Aydogan, C., K. Veyis, Y. Fatma, S. Huma \& D. Adil. 2013. Enantio separation of Ofloxacin by Ligand Exchange Capillary Electrophoresis Using L-Histidin Modified Nanoparticles as Chiral Ligand. Pakistan. University of Sindh.

Fessenden, R. J., Fessenden, J. S. 1992, Kimia Organik, Edisi ketiga. Penerbit. Erlangga, Jakarta

Schmid, M.G., \& Gübitz, G. 2011. Chiral Separation By Ligand-Exchange. Macedonian Journal of Chemistry and Chemical Engineering, Vol. 30, No. 2, pp. 127-137.

Shao, B., Suna, X., Zhang, J., Hub, J., Dong, H., \& Yanga, Y. 2008. Determination of ofloxacin enantiomers in sewage using two-step solidphase extraction and liquid chromatography with fluorescence detection. Journal of Chromatography A, 1182, 77-84

Tian, M., Row, K.H. \& Row, H.S. 2010. Chiral separation of ofloxacin enantiomers by ligand exchange chromatography. Monatsh Chem. 141: 285-290.

Wang, Z., Wang, S., Zhu, F., Chen, Z., Yu, L., \& Zeng, S. 2012. Determination of enantiomeric impurity in besifloxacin hydrochloride by chiral high-performance liquid chromatography with precolumn derivatization. Chirality. 24(7):52631. doi: 10.1002/chir.22042. 